\title{
EVIDENCE FOR THE EXISTENCE OF A PROTEASOME IN TOXOPLASMA GONDII: INTRACELLULAR LOCALIZATION AND SPECIFIC PEPTIDASE ACTIVITIES
}

\author{
PAUGAM A.*, CREUZET C.*, DUPOUY-CAMET J.* \& ROISIN M.P.*
}

\section{Summary :}

The proteasome is a large intracellular protein complex whose main function is proteolytic removal of damaged proteins. It has recently been shown that the proteasome has a crucial role in the pathogenesis of protozoan parasites. We attempted to characterize the proteasome of $T$. gondii (RH strain). In immunoblot experiments, we showed that MCP231 monoclonal antibody, directed against the human 205 proteasome, labelled homologous proteins in $T$. gondii with a pattern similar to that observed in mammalian cells. The study of in vitro proteolytic activities showed that chymotrypsin-like activity (the only activity obtained with archaebacterial was present in Toxoplasma, with $K_{m}$ and specific activity values close to those observed with eukaryotic cells. Immunofluorescence studies showed that the Toxoplasma proteasome predominated in the cytosol.

KEY WORDS : Toxoplasma gondii, proteasome, immunoblotting, chymotrypsinlike, trypsin-like, fluorescent antibody.

\section{INTRODUCTION}

T The proteasome is a non lysosomal large multisubunit protease complex that is ubiquitous in eukaryotic cells (Bochtler et al., 1999; Dahlmann et al., 1989). Recent studies have shown that the proteasome is involved in the regulation of key cellular processes such as cell cycle progression, oncogenesis, transcription, development, growth and atrophy of development tissues, substrate flux through metabolic pathways, selective elimination of abnormal proteins, and antigen processing (DeMartino \& Slaughter, 1999). The proteasome plays a key role in the regulation of numerous transcription factors (Hilt \& Wolf, 1996). Electron microscopy and X-ray crystallography of proteasomes from Thermoplasma acidophilum (Baumeister et al., 1998) and Saccharomyces cerevisae (Groll et al., 1997) revealed a cylindrical structure composed of four rings with a narrow channel run-

\footnotetext{
* Signalisation et Parasites EA 24-99 INSERM U 529, CHU Cochin, Université Paris V, 27, rue du Faubourg Saint- Jacques, 75014 Paris, France.

Correspondence: A. Paugam.

Tel.: +33 (0)1 58412251 - Fax: +33 (0)1 58412245 .

E-mail: andre.paugam@cch.ap-hop-paris.fr
}

Résumé : MISE EN ÉVIDENCE DU PROTÉASOME DE TOXOPLASMA GONDI: LOCALISATION INTRACELLULAIRE ET ACTIVITÉS SPÉCIFIQUES PEPTIDASIQUES

Le protéasome est un complexe protéique cellulaire dont le rôle essentiel est la protéolyse des protéines anormales. Son implication dans la pathogénicité des protozoaires parasites a pu être démontrée récemment. Notre étude avait pour but de caractériser le protéasome de T. gondii (souche RH). Par immunoblot, nous avons montré que le protéasome de toxoplasme était détecté à l'aide de l'anticorps monoclonal MCP231, dirigé contre la partie $20 S$ du protéasome humain, le profil d'immunomarquage étant identique à celui obtenu avec différentes cellules de mammifères. L'étude des activités protéolytiques a mis en évidence une activité dite chimiotrypsine-similaire /seule activité retrouvée chez les archéobactéries) dont le $K_{m}$ et l'activité spécifique sont proches de celles retrouvées chez les cellules eucaryotes. Par immunofluorescence, la localisation du protéasome de toxoplasme apparaît essentiellement cytoplasmique.

MOTS CLÉS : Toxoplasma gondii, protéasome, trypsine-similaire, chimiotrypsine similaire, immunoblot, immunofluorescence.

ning through the center of the structure. Each ring consists of seven subunits classified as $\alpha$ and $\beta$ $(7 \alpha 7 \beta 7 \beta 7 \alpha)$ on the basis of the simpler proteasome found in the archaebacterium Thermoplasma acidophilum. Proteins are hydrolyzed inside the cylinder sites located on $\alpha$-subunits. In eukaryotic cells, the proteasome consists of two complexes, namely the $20 \mathrm{~S}$ proteasome, which forms the proteolytic core, and the $26 \mathrm{~S}$ proteasome, which consists of the $20 \mathrm{~S}$ proteasome and a complex regulator (PA 700) which confers ATPdependency and ubiquitinated substrate specificity on the enzyme (Ferell et al., 2000). The proteasome, previously described as a multicatalytic proteinase complex, has several distinct peptidase activities. It hydrolyses small peptides whose carboxyl end contains basic, hydrophobic and acidic amino acids (Goldberg, 1995). The first two specificities are often referred to as the trypsin-like (basic) and chymotrypsin-like (hydrophobic) activities (Arribas \& Castano, 1993; Orlowski \& Wilk, 1988). The Thermoplasma proteasome contains only one type of active site and primarily exhibits chymotrypsin-like activity (Dahlmann et al., 1992). Presumably, during evolution from the prokaryote to the eukaryotic proteasome, the active site developed increasing (but not absolute) specificities (Coux et al., 
1996). Proteases play an important role in the pathogenic mechanisms and differentiation of protozoan parasites; proteasome function has recently been found to play a role in the life cycle progression of the parasites Trypanosoma cruzi (Gonzalez et al., 1996) and T. brucei (Mutomba et al., 1997). Evidence for the presence of proteasomes in Entamoeba histolytica (Scholze et al., 1995) and Leishmania mexicana (Robertson, 1999) has also been reported. The potential of proteasome inhibitors for the treatment of malaria has been highlighted in an experimental model (Gantt et al., 1998), and Shaw recently reported the inhibition of Toxoplasma gondii growth and replication by proteasome inhibitors (Shaw et al., 2000). However, little is known of proteasome distribution and activity in protozoan parasites.

The objectives of this study were to detect proteasomes in Toxoplasma by means of immunoblot and immunofluorescence, and to characterize Toxoplasma peptidase activity in soluble cell extracts in comparison with HeLa cells

\section{MATERIALS AND METHODS}

\section{T. GONDII ISOLATION AND CELL CULTURE}

1 he RH strain of Toxoplasma gondii (Sabin, 1941) was maintained by serial passage in IOPS/OF1 Swiss male mice (Iffa Credo, France). Tachyzoites were harvested from peritoneal fluid of mice infected four days earlier. Mice were killed and sterile saline was injected into the peritoneal cavity. Tachyzoites were recovered with a syringe. After two filtration steps on

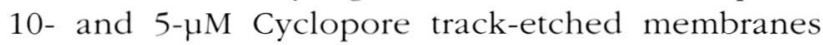
(Whatman), the recovered fluid was centrifuged for 10 min at 1,000 g. The pellet was washed and resuspended in phosphate buffered saline (PBS) and centrifuged for $15 \mathrm{~min}$ at $20,000 \mathrm{~g}$. The pellet was immediately stored at $-20^{\circ} \mathrm{C}$ for immunoblotting and peptidase assays. NIH-3T3 murine fibroblast cells and HeLa cells were grown on 22- $\mathrm{mm}^{2}$ glass coverslips (Marienfeld, Nr. 1) in Dulbecco's modified Eagle's medium pH 7.2 (Life Technologies), supplemented with $10 \%$ fetal calf serum, $5 \mathrm{IU} / \mathrm{ml}$ penicillin and $5 \mu \mathrm{g} / \mathrm{ml}$ streptomycin at $37^{\circ} \mathrm{C}$ in humidified $5 \% \mathrm{CO}_{2}$-air. $\mathrm{NIH}-3 \mathrm{~T} 3$ murine fibroblasts were infected with tachyzoites $\left(\sim 10^{5}\right.$ parasites $\left./ \mathrm{ml}\right)$. Parasites were harvested shortly after complete host-cell lysis and purified by filtration as described above. Free tachyzoites were centrifuged for $10 \mathrm{~min}$ at $600 \mathrm{~g}$ at room temperature, then washed and deposited on coverslips for immunofluorescence studies (see below).

\section{PROTEIN AND PEPTIDASE ASSAYS}

The synthetic fluorogenic substrates succinyl-leucylleucyl-valyl-tyrosyl-4-methylcoumaryl-7-amide (Suc-
LLVY-AMC) and succinyl-leucyl-seryl-threonyl-arginyl4-methylcoumaryl-7-amide (Suc-LSTR-AMC) were purchased from Sigma Chemical Co. The protein concentration was determined by the Bradford microassay method (Bradford, 1976) using $\gamma$-globulin as standard. Stock solutions of the peptide substrates were prepared as follows: LLVY and LSTR were diluted to $20 \mathrm{mM}$ in $100 \%$ DMSO and stored at $-20^{\circ} \mathrm{C}$. Prior to the proteolytic assay, substrates were diluted in Tris- $\mathrm{HCl}$ (50 $\mathrm{mM} \mathrm{pH} \mathrm{7.5).} \mathrm{For} \mathrm{the} \mathrm{determination} \mathrm{of} \mathrm{K}_{\mathrm{m}}-$ and activity - values, a wide range of LLVY and LSTR concentrations was used (10 to $2,000 \mu \mathrm{M})$. Frozen cells were rapidly thawed and homogenized at $4^{\circ} \mathrm{C}$ in $100 \mu \mathrm{l}$ of $25 \mathrm{mM}$ Tris $\mathrm{pH} 7.5$ then frozen again at $-80^{\circ} \mathrm{C}$ for at least $10 \mathrm{~min}$ before rethawing. The combination of hypotonic buffer treatment and repeated freezing caused complete lysis. The protein concentration in the reaction mixture was $25 \mu \mathrm{g}$ per sample. At the start of the proteolytic assay, $50 \mu$ l of sample solution and $50 \mu \mathrm{l}$ of substrate were added at $37^{\circ} \mathrm{C}$ to individual wells of 96-well plates (Nunc) and the fluorescence of the cleavage product was detected at an emission wavelength of $440 \mathrm{~nm}$ (excitation wavelength $380 \mathrm{~nm}$ ) in a Wallac Victor spectrofluorimeter. A standard curve of methylcoumaryl-7-amide (AMC) from 0.5 to $100 \mu \mathrm{M}$ was prepared to express proteolytic activity as picomoles of AMC per minute and milligram of protein.

\section{ANTIBODIES}

MCP-231, a mouse monoclonal antibody against 20S human proteasomes, was obtained from Affiniti Research Products (UK). This antibody reacts with the phylogenetically preserved probox 1 motif shared by all $\alpha$-type subunits ( $\mathrm{HC} 2, \mathrm{HC} 3, \mathrm{HC} 8, \mathrm{HC}$, Iota and Zeta); it reacts with proteasomes of several species, including higher plants, when tested on immunoblots of SDS/PAGE gels, yielding two main bands of 29 and 32 kDa (Hendil et al., 1995; Kopp et al., 1997; Tanaka \& Tsurumi, 1997). A rabbit polyclonal antibody against the 20 s proteasome "core" was obtained from Affiniti. This antibody was raised by rabbit immunization with a proteasome preparation from human red blood cells Western blotting shows bands attributable to "core" subunits at $25-30 \mathrm{kDa}$. This antibody has been shown to react with human, mouse and yeast proteasomes (Kopp et al., 1997; Tanaka \& Tsurumi, 1997). Rabbit immunserum against liver rat proteasomes was a generous gift from B. Friguet (Conconi et al., 1996).

\section{POLYACRYLAMIDE GEL ELECTROPHORESIS AND IMMUNOBLOTTING}

Immunoblot analysis was performed, in the same experiment, with Toxoplasma gondi, HeLa cells and NIH3T3 murine fibroblast cells. The protein extracts were prepared at $4^{\circ} \mathrm{C}$. The cells were lysed in cold lysis 
buffer containing $1 \%$ NP40, $0.1 \%$ SDS, $158 \mathrm{mM} \mathrm{NaCl}$, $10 \mathrm{mM}$ Tris $\mathrm{pH} 7.8,1 \mathrm{mM}$ phenylmethylsulfonylfluoride and $1 \mathrm{mM} \mathrm{Na}_{3} \mathrm{VO}_{4}$. The cell suspensions were then centrifuged for $20 \mathrm{~min}$ at $12,000 \mathrm{~g}$ at $4^{\circ} \mathrm{C}$. We tested the supernatant and pellet of each cell type. Pellets were homogenized in $100 \mu \mathrm{l}$ of $25 \mathrm{mM}$ Tris $\mathrm{pH} 7.8$. The protein concentration was determined as described above. Equal amounts of protein $(50 \mu \mathrm{g})$ from the supernatant and pellet were separated by electrophoresis on SDS- $12.5 \%$ polyacrylamide gel and transferred electrophoretically onto a nitrocellulose membrane. The membrane was incubated for $2 \mathrm{~h}$ at room temperature with $0.25 \%$ gelatin in Tris-buffered saline (10 mM Tris pH 7.5, $150 \mathrm{mM} \mathrm{NaCl)} \mathrm{containing} 0.05 \%$ Tween 20 (TBST) to block nonspecific binding sites. The membrane was then incubated for $1.5 \mathrm{~h}$ at room temperature with the MCP231 anti-20S proteasome monoclonal antibody at 1:2,000 dilution (Affiniti). After extensive washing with TBST, the membrane was incubated for two hours with horseradish peroxidaseconjugated goat anti-mouse IgG (Dako) diluted 1:5,000, then washed with blocking buffer. Proteins were visualized after chemiluminescence staining, following the manufacturer's protocol (ECL, Amersham).

\section{IMMUNOCYTOFLUORESCENCE}

AND CONFOCAL MICROSCOPY

Cells grown on $22-\mathrm{mm}^{2}$ glass coverslips were used for immunocytofluorescence studies. The cells were washed three times with PBS then fixed with $4 \%$ paraformaldehyde in PBS for $10 \mathrm{~min}$. This and all subsequent steps were performed at room temperature. Permeabilization was obtained with $1 \%$ Triton X100 in PBS for 5 min. Preincubation for 30 min with PBS + $1 \%$ bovine serum albumin, Fraction V (Sigma) + $1 \%$ normal goat serum (GS) was followed by incubation for $1.5 \mathrm{~h}$ with proteasome antibody at 1:50 dilution in PBS supplemented with $1 \%$ GS. After washing in PBS supplemented with $1 \%$ BSA, $1 \%$ GS and $0.1 \%$ Triton, the secondary fluorescent antibody (FITC-coupled goat antibody, Sigma) at 1:100 dilution was added for $40 \mathrm{~min}$. Final washes were followed by mounting in Vectashield (Vector, Biosys). Coverslips were exa-

Fig. 1. - SDS-PAGE and immunoblotting of cell lysates with mAb MCP231 (12.5\% acrylamide gel).

1: Human cells (HeLa).

2: Toxoplasma gondii cells,

3: Mouse cells (NIH-3T3 fibroblasts).

4: Rat cells (brain homogenate).

s: Supernatant. p: Pellet.

Equal amounts of protein were subjected to SDS-PAGE as described in Materials and Methods. mined using a BioRad MRC-1000 device mounted on a Nikon Optiphot II equipped with a 40x objective (Plan apo: NA 1.4). Confocal sections were taken at $0.5-\mu \mathrm{m}$ focus steps. HeLa cells and NIH-3T3 murine fibrobasts were used for comparison. Labeling was considered specific, as no labeling was observed when the primary antibody was omitted.

\section{RESULTS AND DISCUSSION}

\section{IMMUNOBLOTTING}

S upernatants and pellets of Toxoplasma, HeLa cells and mouse cells (NIH-3T3) containing the same amount of protein $(50 \mu \mathrm{g})$ were fractionated by SDS-PAGE and blotted to nitrocellulose membranes as described in Material and Methods. We tested a rat brain lysate as specific control, because immunoblot analysis of purified proteasomes and total brain homogenate with anti-proteasome antibody yields the same pattern (three polypeptide bands around $30 \mathrm{kDa}$ ) (Mengual et al., 1996). Immunoblotting of cell lysates with a mouse Mab MCP231 yielded three different bands at 29, 30 and $32 \mathrm{kDa}$ with $T$. gondii (Fig. 1). The two most intensely labeled bands had relative molecular weights of 29 and $32 \mathrm{kDa}$. An identical pattern was observed with the three animal cell types. Although an equal amount of protein was used, supernatants yielded more-intense bands than pellets, confirming that in Toxoplasma, as in other eukaryotic cells, proteasomes are mainly present in the cytosolic fraction (Palmer et al., 1996). The MCP231 antibody reacts with a motif common to all $\alpha$-type subunits (HC2, HC3, HC8, HC9, Iota and Zeta), which is phylogenetically preserved (Hendil et al., 1995). To our knowledge, MCP231 has only been used twice to detect proteasomes in protozoan parasites. Scholze et al. (1995) showed that MCP231 crossreacted with a soluble E. histolytica extract. Emmerlich et al. (1999) observed immunoblot crossreactivity with MCP231 and Giardia lamblia proteins; MCP231 was the only antibody showing cross-reactivity among several other antibodies directed against the proteasome. We observed a similar lack of cross-reac-

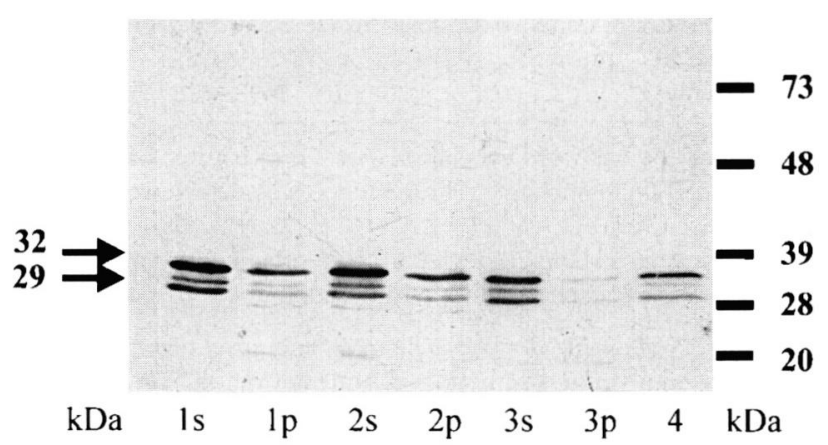


tivity with the $T$. gondii proteasome when we used an antiserum raised against the $20 \mathrm{~S}$ human red cell proteasome (see Materials and Methods) in immunoblot experiments. Hua et al. (1996) demonstrated that the $20 \mathrm{~S}$ proteasome of Trypanosoma brucei showed no cross-reactivity with an antiserum raised against the human 20 s proteasome. In addition, To et al. (1997), using polyclonal antibodies raised against the $T$. brucei proteasome, observed no cross reactivity with proteasomes from rat blood cells. These data point to species-specific differences among proteasomes of protozoan parasites and mammalian cells.

\section{Proteolytic activities}

Proteolytic activities were measured with fluorogenic peptides as described above. The hydrolytic reaction rate, when tested as a function of the enzyme concentration and incubation time, was linear, indicating that the enzyme was stable in the assay conditions used (data not shown).

The two peptide substrates tested here exhibited different properties with regard to substrate requirements and rate of hydrolysis; Lineweaver-Burke plots of proteolytic activity at different substrate concentrations allowed us to determine the $\mathrm{K}_{\mathrm{m}}$ of the two substrates. The derived $\mathrm{K}_{\mathrm{m}}$ and specific activity values are listed in Table I. Determination of the $\mathrm{K}_{\mathrm{m}}$ value revealed higher binding of the Toxoplasma proteasome to the LLVY substrate $\left(\mathrm{K}_{\mathrm{m}}=60 \mu \mathrm{M}\right)$ than to the LSTR substrate $\left(\mathrm{K}_{\mathrm{m}}=260 \mu \mathrm{M}\right)$, as observed with HeLa cells $\left(\mathrm{K}_{\mathrm{m}}=80\right.$ and $240 \mu \mathrm{M}$, respectively). The proteasome activities. of Toxoplasma and HeLa cells had the same magnitude for LLVY (16.7 versus $32 \mathrm{pmol} . \mathrm{min}^{-1} \cdot \mathrm{mg}^{-1}$ ) but very different magnitudes for LSTR (76.2 for Toxoplasma versus $1568 \mathrm{pmol} . \mathrm{min}^{-1} \cdot \mathrm{mg}^{-1}$ for HeLa cells). To determine if the HeLa cell LSTR value was representative of mammalian cells, we also tested Toxoplasma cells and NIH-3T3 mouse cells simultaneously, and obtained similar results to those obtained with Toxoplasma and HeLa cells (data not shown).

\begin{tabular}{lccccc}
\hline \multirow{2}{*}{$\begin{array}{c}\text { Catalytic } \\
\text { activity }\end{array}$} & \multicolumn{2}{c}{$\mathbf{a}_{\mathbf{m}} \mathbf{( 4 )}$} & & \multicolumn{2}{c}{ aspecific activity (7) } \\
\cline { 2 - 3 } & HeLa & T. gondii & & HeLa & T. gondii \\
\hline $\begin{array}{l}\text { Chymotrypsin-like } \\
\begin{array}{l}\text { Suc-LLVY-AMC } \\
\text { Trypsin-like }\end{array}\end{array}$ & $0.08 \pm 0.02$ & $0.06 \pm 0.01$ & $32 \pm 7.3$ & $16.7 \pm 5.2$ \\
\begin{tabular}{l} 
Suc-LSTR-AMC \\
\hline
\end{tabular} & $0.24 \pm 0.05$ & $0.26 \pm 0.03$ & & $1598 \pm 328$ & $76.2 \pm 10.07$ \\
\hline
\end{tabular}

Proteolytic activities were measured after $2 \mathrm{~h}$ of incubation ( $\mathrm{pH} 7.5$; $37^{\circ} \mathrm{C}$ ) with $200 \mu \mathrm{M}$ substrate. Fluorescence was detected at $460 \mathrm{~nm}$ (355 nm excitation).

${ }^{a}$ : Values (means \pm standard deviation) were obtained from the numbers of experiments shown in parentheses.

Table I. - Proteasome-derived $\mathrm{K}_{\mathrm{m}}(\mathrm{mM})$ and proteolytic activities $\left(\right.$ pmol. $\mathrm{min}^{-1} \cdot \mathrm{mg}^{-1}$ ) for synthetic substrates. Comparison between results obtained with Toxoplasma cell lysates and HeLa cell lysates.
Few data are available on proteasome peptidase activities of protozoan parasites, and most have been obtained with purified $20 \mathrm{~S}$ proteasomes. The chymotrypsin-like activities (LLVY-AMC fluorogenic substrate, expressed in nmol. $\mathrm{mg}^{-1} \cdot \mathrm{min}^{-1}$ ) observed with purified proteasomes of protozoan parasites range from 0 with Giardia lambia (Emmerlich et al., 1999) to 6.2-69.2 with Trypanosoma brucei (Hua et al., 1996; To et al., 1997); 9.4 with Leishmania mexicana (Roberston, 1999) and 20.44 with Entamoeba invadens (Gonzalez et al., 1996). We chose to work with crude cell extracts and not with purified proteasomes for the following reasons. Proteasomes in crude cell extracts are more likely to retain their native activities (Driscoll et al., 1992). Indeed, according to various studies, isolation and purification processes activate the proteasome and lead to structural changes (Ma et al., 1992). This could explain why Emmerlich et al. (1999) after purification of Giardia lamblia 20 s proteasomes, failed to observe significant activity on a range of fluorogenic peptides that are hydrolyzed by the proteasomes of other organisms. Published activity values of crude parasite proteasome extracts are scarce. However, protease activities measured with Suc-LLVY-AMC as substrate have been reported for crude extracts of Entamoeba invadens (Gonzalez et al., 1996) and E. histolytica (Scholze et al., 1995). The observed activities -0.016 and $0.01 \mathrm{nmol} / \mathrm{min} . \mathrm{mg}$, respectively - were close to those we obtained with T. gondii $(0.011 \mathrm{nmol} / \mathrm{min} . \mathrm{mg})$. We found no published studies using LSTR and crude parasite extracts, but our results suggest that proteasome of $T$. gondii has lower trypsin-like activity to that of mammalian cell (1598 pmol. $\mathrm{min}^{-1}$.mg for HeLa versus 76 pmol.min ${ }^{-1} . \mathrm{mg}$ for Toxoplasma). The proteolytic activity of the Toxoplasma proteasome seems closer to that of prokaryotic proteasomes than that of mammalian proteasomes, the former showing only chymotrypsin-like activity (de Mot et al., 1999).

\section{IMMUNOFLUORESCENCE MICROSCOPY}

We tested the Mab MCP231 and two rabbit antisera, one against human proteasomes (Affiniti) and the other against rat proteasomes (generously provided by Pr B. Friguet, Paris VI University). As the rabbit antiserum against rat proteasomes gave the clearest immunofluorescence pattern, we only discuss the results obtained with this antibody. In the same experiment, we simultaneously labeled Toxoplasma, HeLa cells and NIH-3T3 murine fibrobast cell crude extracts. The proteasome of NIH-3T3 murine fibroblast cells and HeLa cells was localized in the cytoplasm and the nucleus. The cytoplasm showed fine granular staining, nuclear staining was stronger, and nucleoli were not labeled (Fig. 2A). This pattern is that usually observed with eukaryotic cells (Machiels et al., 1995). With Toxo- 

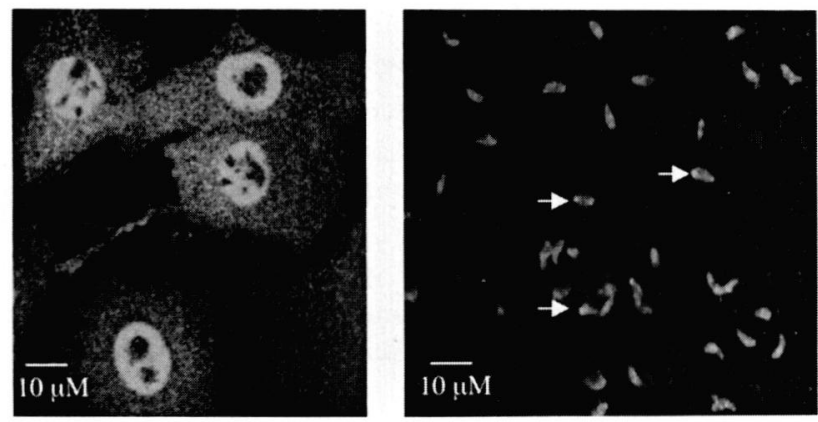

A

B

Fig. 2. - Immunofluorescence microscopy of cells cultured in vitro and labeled with a rabbit polydonal antibody raised against rat proteasomes.

A: NIH-3T3 murine fibroblast cells

Note that both the cytoplasm and the nucleus were labeled.

B: Free T. gondii from 3T3 cell culture.

Agregates of cytoplasmic fluorescence are arrowed. Absence of nucleal fluorescence was visualized by staining DNA with 4.6-diamidino-2-phenylindole (DAPI) corresponding to blue coloration of the nucleus.

plasma (Fig. 2B), the cytoplasm was labeled while the nucleus was not. In a wide variety of multicellular organisms the proteasome is found in both the cytoplasm and the nucleus (Tanaka et al., 1990; Amsterdam et al., 1993). Subcellular fractionation experiments have generally shown that proteasomes are more abundant in the cytosol than in the nucleoplasm (Russel et al., 1999). Densitometric analysis of western blots obtained in cellfractionation experiments shows that, for the same amount of bulk protein in each fraction, the level of proteasomes is about 10-fold higher in the cytosol than in the nucleus (Palmer et al., 1996), although the exact ratio varies with the cell type and growth conditions (Peters et al., 1994; Yang et al., 1995). In addition, immunofluorescence experiments with mammalian cells have shown that the proteasome ratio varies in a complex manner through the cell cycle (Nannmark et al., 1996; Knecht et al., 1991; Russel et al., 1999). To detect possible changes in the intracellular localization of the Toxoplasma proteasome during mitosis, we stained NIH-3T3 murine fibroblast cells infected by Toxoplasma (data not shown). Despite the intracellular multiplication of Toxoplasma, we observed no nuclear labeling, suggesting that the Toxoplasma proteasome is most abundant in the cytoplasm. Two distribution patterns were seen: fluorescence was dispersed throughout the cell in $90 \%$ of parasites, while it showed aggregates of different sizes and shape in $10 \%$ of parasites (Fig. 2B, arrowheads). The aggregates tended to accumulate at the basal pole of the parasite, where the endoplasmic reticulum is principally located (Hager et al., 1999). This difference in labeling could also be due to the presence of parasites at different stages of the cell cycle (Reits et al., 1997). Thus, although the intracellular distribution of mammalian proteasomes remains somewhat controversial (Hirch \& Ploegh, 2000), the T. gondii proteasome seems to be exclusively located in the cytoplasm.

\section{CONCLUSION}

W

e report evidence that $T$. gondii possesses a proteasome. In immunoblot experiments, T. gondii crude extracts reacted strongly with the monoclonal antibody MCP231 but was only weakly reactive with a polyclonal antibody against the $20 S$ human proteasome. The chymotrypsin-like activity of the $T$. gondii proteasome was similar to that of eukaryotic proteasomes, although the trypsin-like activity of the former was far weaker. Localization studies of the Toxoplasma proteasome based on immunofluorescence and confocal microscopy suggested a principally cytoplasmic location and no nuclear labelling. These data point to differences between the Toxoplasma proteasome and the mammalian $20 \mathrm{~S}$ proteasome.

\section{ACKNOWLEDGEMENTS}

W

e thank Isabelle Bouchaert (Institut Cochin de Génétique Moléculaire, Paris) for her expert technical assistance with confocal microscopy. We are very grateful to Anne-Laure Bulteau and Bertrand Friguet (Laboratoire de Biologie et de Biochimie cellulaire, Université Paris 7) for fruitful discussions. We thank David Young for editing the English revision of the manuscript.

\section{REFERENCES}

Amsterdam A., Pitzer F. \& Baumeister W. Changes in intracellular localization of proteasomes in immortalized ovarian granulosa cells during mitosis associated with a role in cell cycle control. Proceedings of the National Academy of Sciences of the United States of America, 1993, 90, 99103 .

Arribas J. \& Castano J. A comparative study of the chimiotrypsin-like activity of the rat liver multicatalytic proteinase and the ClpP from Escherichia coli. Journal of Biological Chemistry, 1993, 268, 21165-21171.

Baumeister W., Walz J., Zuhl F. \& Seemuller E. The proteasome: paradigm of a self-compartmentalizing protease. Cell, 1998, 92, 367-380.

Bochtler M., Ditzel L., Groll M., Hartmann C. \& Huber R. The proteasome. Annual Review of Biophysics and Structure, 1999, 28, 295-317. 
BRADFORD M. A rapid and sensitive method for the quantitation of microgram quantities of protein utilizing the principle of protein-dye binding. Analytical Biochemistry, $1976,72,248-254$.

Conconi M., Sweda L., Levine R., Stadtman E. \& Friguet B. Age-related decline of rat liver multicatalytic proteinase activity and protection from oxidative inactivation by heatshock protein 90. Archives Biochemistry Biophysics, 1996, 331, 232-240.

Coux O., Tanaka K. \& Goldberg A. Structure and functions of the $20 \mathrm{~S}$ and $26 \mathrm{~S}$ proteasomes. Annual Review of Biochemistry, 1996, 65, 801-847.

Dahlmann B., Kopp F., KueHn L. et al. The multicatalytic proteinase (prosome) is ubiquitous from eucaryotes to archaebacteria. FEBS Letters, 1989, 17, 125-131.

Dahlmann B., Kuehn L., Grziwa A., Zwickl P. \& Baumeister W. Biochemical properties of the proteasome from Thermoplasma acidophilum. European Journal of Biochemistry, 1992, 208, 789-797.

de Mot R., Nagy I., Walz J. \& Baumeister W. Proteasomes and other self-compartmentalizing proteases in prokaryotes. Trends in Microbiology, 1999, 7, 88-93.

De Martino G. \& Slaughter C. The proteasome, a novel protease regulated by multiple mechanisms. Journal of Biological Chemistry, 1999, 32, 2213-2226.

Driscoll J., Frydman J. \& Goldberg A. An ATP-stabilized inhibitor of the proteasome is a compoment of the $1500-\mathrm{kDa}$ ubiquitin conjugate-degrading complex. Proceedings of the National Academy of Sciences of the United States of America, 1992, 89, 4986-4990.

Emmerlich V., Santarius U., Bakker-Grunwald T. \& Scholze H. Isolation and subunit composition of the $20 S$ proteasome of Giardia lamblia. Molecular and Biochemical Parasitology, 1999, 100, 131-134.

FERrell K., Wilkinson R., Dubiel W. \& Gordon C. Regulatory subunit interactions of the $26 \mathrm{~S}$ proteasome, a complex problem. Trends in Biochemical Science, 2000, 25, 83-88.

Gantt S.M., Myung J.M., Briones M.R. et al. Proteasome inhibitors block development of Plasmodium spp. Antimicrobial Agents and Chemotherapy, 1998, 42, 2731-2738.

GOLDBERG A. Functions of the proteasome: the lysis at the end of the tunnel. Science, 1995, 268, 522-523.

Gonzalez J., Ramalho-Pinto F.J., Frevert U. et al. Proteasome activity is required for the stage-specific transformation of a protozoan parasite. Journal of Experimental Medicine, 1996, 184, 1909-1918.

Groll M., Ditzel L., Lowe J. et al. Structure of $20 \mathrm{~S}$ proteasome from yeast at 2.4 A resolution. Nature, 1997, 386, 463-471.

Hager K., Striepen B., Tilney L. \& Ross D. The nuclear envelope serves as an intermediary between the ER and Golgi complex in the intracellular parasite Toxoplasma gondii. Journal of Cell Science, 1999, 112, 2631-2638.

Hendil K., Kristensen P. \& Uerkvitz W. Human proteasomes analysed with monoclonal antibodies. Biochemical Journal, $1995,305,245-252$.

HitT W. \& Wolf D. Proteasome: destruction as a programme. Trends in Biochemical Science, 1996, 21, 96-102.
Hirch C. \& Ploegh H. Intracellular targeting of the proteasome. Trends in Cell Biology, 2000, 10, 268-271.

Hua S., To W.Y., Nguyen T.T., Wong M.L. \& Wang C.C. Purification and characterization of proteasomes from Trypanosoma brucei. Molecular and Biochemical Parasitology, 1996, 78, 33-46.

Knecht E., Palmer A., Sweeney S. \& Rivett J. Immunocytochemical localization of the multicatalytic proteinase in rat liver in L-132 cells. Biochemical Society Transactions, 1991, 19, 2935.

Kopp F., Hendil K., Dahlmann B., Kristensen P., Sobeck A. \& UERBITZ W. Subunit arrangement in the human $20 \mathrm{~S}$ proteasome. Proceedings of the National Academy of Sciences of the United States of America, 1997, 94, 2939-2944.

Ma C., Slaughter C. \& De Martino G. Identification, purification and characterization of a protein activator (PA28) od the $20 S$ proteasome (macropain). Journal of Biological Chemistry, 1992, 267, 10515-10523.

Machiels B., Henfling M., Broers J., Hendil K. \& Ramaekers F. Changes in immunocytochemical detectability of proteasome epitopes depending on cell growth and fixation conditions of lung cancer cell lines. European Journal of Cell Biology, 1995, 66, 282-292.

Mengual E., Arizti P., Rodrigo J., Giménez-Amaya J. \& CasTANO J. Immunohistochemical distribution and electron microscopic subcellular localization of the proteasome in the rat CNS. Journal of the Neurological Science, 1996, 16, 6331-6341.

Mutomba M., To W., Hyun W. \& Wang C. Inhibition of proteasome activity blocks cell cycle progression at specific phase boundaries in African trypanosomes. Molecular and Biochemical Parasitology, 1997, 90, 491-504.

Nannmark U., Kitson R., Johansson B., Rivett J. \& Goldfard R. Immunocytochemical localization of multicatalytic protease complex (proteasome) during generation of murine IL-2 activated natural killer (A-NK) cells. European Journal of Cell Biology, 1996, 71, 402-408.

ORLOWSKI M. \& WILK S. A multicatalytic protease complex from pituitary that form enkephalin and enkephalin containing peptides. Biochemical and Biophysical Research Communications, 1988, 101, 814-822.

Palmer A., Rivett A., Thomson S. et al. Subpopulations of proteasomes in rat liver nuclei, microsomes and cytosol. Biochemical Journal, 1996, 316, 401-407.

Peters J.-M., Franck W. \& Kleinschmidt J. Distinct $19 S$ and $20 \mathrm{~S}$ subcomplexes of the $26 \mathrm{~S}$ proteasome and their distribution in the nucleus and in the cytoplasm. Journal of Biological Chemistry, 1994, 269, 7709-7718.

Reits E., Benham A., Plougastel B., Neefjes J. \& Trowsdale J. Dynamics of proteasome distribution in living cells. EMBO Journal, 1997, 16, 6087-6094.

Robertson C. The Leishmania mexicana proteasome. Molecular and Biochemical Parasitology, 1999, 103, 49-60.

Russell S., Steger K. \& Johnston S. Subcellular localization, stoichiometry, and protein levels of $26 \mathrm{~S}$ proteasome subunits in yeast. Journal of Biological Chemistry, 1999, 274, 21943-21952. 
SABIN A. Toxoplasmic encephalitis in children. Journal of American Medical Association, 1941, 116, 801-807.

Scholze H., Frey S., Cejka Z. \& BaKke-Grunwald T. Evidence for the existence of both proteasomes and a novel high molecular weight peptidase in Entamoeba bistolytica. Journal of Biological Chemistry, 1995, 271, 6212-6216.

Shaw M.K., He C.Y., Roos D.S. \& Tilney L.G. Proteasome inhibitors block intracellular growth and replication of Toxoplasma gondii. Parasitology, 2000, 121, 35-47.

TANAKa K. \& Tsurumi C. The $26 \mathrm{~S}$ proteasome: subunits and functions. Molecular Biology Reports, 1997, 24, 3-11.

Tanaka K., Yoshimura T., Tamura T., Fujiwara T., KumaTORI A. \& ICHIARA A. Possible mechanism of nuclear translocation of proteasomes. FEBS Letters, 1990, 271, 41-46.

To W.Y. \& WANG C.C. Identification and characterization of an activated $20 \mathrm{~S}$ proteasome in Trypanosoma brucei. FEBS Letters, 1997, 404, 253-62.

YANG Y., FrÜH K. \& Ahn K., Peterson P. In vivo assembly of proteasomal complexes implications for antigen processing. Journal of Biological Chemistry, 1995, 270, 2768727694.

Reçu le 24 avril 2001 Accepté le 29 juin 2001 